\title{
WHEN WORLDS COLLIDE
}

\section{THE CONTEMPORARY MUSEUM AS ART GALLERY}

\section{Christopher R. Marshall}

In 1716, Filippo Bonnani, then curator of the Museo Kircheriano at the Collegio Romano in Rome, felt compelled to correct a common misconception of visitors to his museum. Bonnani presided over the city's most significant collection of art, natural history and ethnographic material that was comparable in its scope to the great kunst- and wunderkammers of Northern Europe. Yet visitors nonetheless tended to refer to his collection as a galleria. For Bonnani, this diminished the seriousness of his project. As he put it, the term 'galleria' should be used to describe collections 'made solely for their magnificence', whereas for his institution 'One should more properly say Museo . . . or, as musaeum alludes, one says a place dedicated to the muses'.[1]

In referring to the Renaissance concept of the locus musus, Bonnani signalled the encyclopaedic aspirations of his museum since, as his readers would have instantly recognized, the muses presided over all aspects of enlightened human activity. He also drew on the long-established spatial distinction between the semiprivate Renaissance humanist study cum museum and the more expansive, public and transitory space of the gallery. In architectural terms, a gallery was accordingly defined as a semi-open loggia or corridor connecting one area of a palace to another (the Galleria degli Uffizi being the quintessential instance of this in sixteenth-century Europe).[2] Bonnani's complaint thus confirms that, at this stage in its development at least, the transit space of the gallery carried associations of leisure, social communication and aesthetic enjoyment that were to be differentiated, in turn, from the more serious and comprehensive aspirations of the museum.

Museums have, of course, long since ceased regarding themselves as semi-private spaces of arcane contemplation. Conversely, no public art gallery would today identify its mission as not involving a fundamental concern with education and public programming of the broadest and most accessible kind. The continued relevance of Bonnani's distinction nonetheless bears reinforcing at the outset of this discussion. If pushed to formulate an inevitably too simplistic generalization to explain this we might venture that museums constitute inherently projective spaces, whereas art galleries remain committed to the ideal of a more self-contained and reflective space.

Museums generally encompass a greater diversity of objects and/or ideas than art galleries and they allow for a greater degree of spatial interactivity as a result. This is as much true of a sixteenth-century wunderkammer as it is of a contemporary air and space museum. This is not to say, on the other hand, that galleries are not

(C) Christopher R. Marshall and Routledge

Christopher R. Marshall, 'When Worlds Collide: The Contemporary Museum as Art Gallery' in Suzanne MacLeod (ed), Reshaping Museum Space: Architecture, Design, Exhibitions (London and New York: Routledge, 2005), pp. 170-84. 
also committed to displaying increasingly divergent art forms and media, particularly those devoted to contemporary art. In relative terms, however, it is nonetheless still striking how little the essential architectural components of the gallery have changed - together with the display regimes that they entail from the time of Bonnani's baroque galleria through to the museological codification of that space in the early public galleries of the eighteenth and nineteenth centuries and on to today.

Besides their greater diversity museum spaces also project more emphatically than galleries in the ways in which their exhibitionary elements have been knitted together, as it were, in order to reach out beyond themselves to convey an integrated message of whatever broader communications agenda the exhibit

is seeking to articulate. This is why museums have traditionally led the field in the development of communications technologies - either through labelling and wall text or, more recently, in the emphasis on interactive displays and multi- media. Much as art galleries might wish to project with all the immediacy and interactivity of contemporary science, nature and social history museums, they are nonetheless bound by an essentially different charter. Their focus, instead, is not so much on the co-ordinated communications message as rather on the autonomy and individuality of the artwork displayed in its own right.

Such an emphasis is accordingly mistrustful of a too overt and heavy-handed emphasis on binding objects together within an overriding didactic programme. Textual interpolation is thus often de-emphasized or presented as somehow secondary to the primary act of viewing. The discrete positioning of room brochures forms one common manifestation of this trend. Further evidence comes more recently in the ways in which information and communication technologies have begun to be integrated into art galleries. Just as these elements are increasingly found in gallery spaces, so too are they increasingly quarantined or minimized in their emphasis relative to the actual artworks in the galleries themselves. The microgalleries in the National Galleries of both London and Washington, DC, for example, are prime instances of this, forming as they do separate zones at either the beginning or the end of the viewer's circulation path.

This essential distinction has created ongoing challenges for galleries that museums, in many respects, have not had to face. We might agree, for example, that a tastefully minimalist and classic white cube installation such as one encounters in Roland Simounet's mid 1980s' renovation of the Musée Picasso, to cite but one of countless examples, runs the risk of decreasing access by virtue of the closed circuit effect that it sets up in the gallery space.[3] Unlike the more outwardly projective spaces of the museum, the display here, beautiful though it undoubtedly is, with its sleek setting and minimal wall text, does not immediately go to the trouble of reaching out beyond its own frame of reference to connect with a non-initiated viewer's experience. Consequently if the viewer does not already recognize Picasso's pre-eminence within the wider traditions of European modernism, together with the mutually reinforcing modernist display regime that his work was constructed for and that the gallery installation further enshrines, then that visitor may well leave this exhibition none the wiser.

This issue, then, of how galleries are to regain the projective space of museums while also continuing to maintain their own divergent emphasis on the individual integrity of the artwork is one that continues to drive their thinking. But while galleries have begun to grapple with this it is interesting to note the extent to which museums have, conversely, themselves been highly attentive to recent developments in contemporary art and gallery design. 
the Primates Gallery of the Natural History Museum, London.[4] This project displays two features that are commonly encountered in recent spaces of this kind. First is the use of contemporary art that is often strategically positioned at the entrance to a display or even to the museum itself as a welcoming, nondidactic element. Works of this kind are commonly intended as eye-catching and evocative indications of the exhibition that follows, yet do not require the visitor to stop and read a didactic label. A second feature is the high aestheticization effect that plays a particularly prominent role in the new entrance to the Earth Galleries. In this instance, although it is a natural history exhibit, the entrance displays have been framed through a classic white cube minimalist aesthetic that is highly reminiscent of contemporary art gallery design.

This aesthetic is not applied for its own sake, but rather to underscore the Museum's point of distinction from traditional natural history exhibits. It uses it more specifically as a means of countering the visually deadening serial effect created by the serried ranks of dead creatures, minerals or other such objects in traditional natural history museums. Instead, the designers have focused attention on a smaller number of isolated and strategically positioned elements. Even the pose of the hippo in the Earth Galleries is significant in this respect. By rotating it away from its 'natural' stance the designers have also achieved a more artificial and thus also more artistic effect. The viewer is accordingly asked to contemplate this specimen not as a serial, didactic component but rather as a beautifully framed aesthetic object in its own right. This is, to be sure, a striking and accessible strategy. Yet the art effect is strong, even arguably distracting to a degree, since it reminds us of nothing so much as the work of a certain English enfant terrible of contemporary art with his predilection for cabinets filled with mutely suspended sharks, cows and other animals.

Across the channel this influence seems further accelerated in the splendid redesign of the Muséum national d'Histoire naturelle in Paris.[5] The centrepiece of this redevelopment is the Grande Galerie de l'Evolution. Here the animals have been liberated from their vitrines in a way that helps to overcome the static and tableau-like effect that is a by-product of the traditional diorama. Here the animals act as a dynamic ensemble of inherently projective elements that at the same time also share the viewer's space. Once again though, the art effect is strong and maybe even to a certain degree counter-productive. In the first instance the display has the effect of decontextualizing the creatures, making them appear as free-floating aesthetic elements on a darkened stage. True, they no longer appear as frozen, tableau elements in three-dimensional paintings, this being another of the chief drawbacks of the traditional diorama. Yet the designers have arguably achieved this at the expense of recasting these beautiful examples of the taxidermist's art as a deluxe sculptural ensemble in the round. Perhaps they are not so dissimilar in this respect from the grand sculptural boulevard created by the installation of nineteenth-century public sculpture along the central aisle of the Musée d'Orsay further down the Seine. The result is a spectacular yet at the same time somewhat distancing view that we are encouraged to take in, in a general scene-setting sense, rather than in a more specifically didactic way.

These few disparate examples should have served to introduce a general trend that is evident across all areas of museum practice today. As these and count- less other initiatives attest, art and art-inspired elements are increasingly being used to open up recently designed museum spaces to a more experiential and evocative form of communications message that seeks to escape the dead hand of a too overt and traditionally didactic display. At the same time, however, the previous discussion should also have begun to raise the issue of the risks involved in these strategies as the traditional roles and expectations of museum spaces become conflated, at times rather confusingly, with added associations and ideas from art galleries. 
If we turn now to look at one example in slightly more detail it is possible to identify a further three key characteristics that initiatives of this kind tend to share. Our case study here is a high-profile Australian instance of the new museology at work, developed in the mid 1990s for the Museum of Sydney.[6] This museum was built over the archaeological remains of the site of the first colonial governor's residence in the city. It was accordingly conceived originally along relatively traditional lines as a reconstructed historic property before being reconceptualized more generally as a museum of the early history of Sydney and its surrounds as viewed from a contemporary pluralist perspective. This new emphasis further encouraged the use of more creative and artistic approaches to exhibition design.

The first feature that this and other museums of this kind demonstrate, is what we might term an integrated approach, whereby contemporary art forms part of a broader strategy to draw on a wider palette of innovative features and specializations that attempt to think outside the box of traditional display. In common with other museums of this kind, therefore, the Museum of Sydney accordingly sought the talents of a range of emergent inter-disciplinary specialists. This includes evocative sound installations by the musician and sound artist, David Chesworth, and a video installation by the writer, film-maker and mediatheorist, Ross Gibson.

Such innovation is also often partly a product of necessity. This is true of the Museum of Sydney in that it did not possess a rich collection of artefacts with which to tell its stories. Many of its art and design elements were thus deployed as alternatives for the missing objects that were otherwise lacking in a traditional sense. So, another key element of this approach is that it often uses art to bolster the muteness or inadequacy of certain kinds of sites and/or objects to communicate to the viewer in traditional museum displays. Historic houses and other categories of heritage site lend themselves particularly well to this approach. Relatively little remains of the building site upon which the Museum of Sydney is located. The Museum thus needed to reconstruct its narrative on the basis of a fairly meagre archaeological site - meagre, that is, in terms of objects that might be considered 'display worthy' in a traditional sense. So the art elements helped to build up a picture that would otherwise have been almost impossible to develop.

Finally, the art elements in museums of this kind can even achieve such a prominence in the overall design as to take the form of highly ambitious commissioned work. These commissions often stand slightly apart from the exhibits them- selves - often again at the entrance - in order to express wider institutional perspectives similar to the role performed by a public sculpture in a prominent civic plaza. Commissioned art of this kind is thus given a major responsibility as regards the projected self-image of the institution in terms of the deeper cultural and ideological values that it seeks to uphold. The prime example of this in the Museum of Sydney is a sculpture and multi-media installation sited at the entrance to the museum - and thus also in this instance literally in the place normally reserved for a civic sculpture. This work is the result of a collab- oration between a white Australian artist, Janet Laurence, and an indigenous Australian artist, Fiona Foley. The Edge of the Trees presents a post-colonial perspective on the early history of white settlement in Sydney, as it imagines the indigenous Eora people of New South Wales standing at the edge of the trees watching Captain Cook and subsequent European colonizers landing on their shoreline. It thus effectively, and also highly evocatively, sets the stage for the narrative of post-colonial perspectives on colonial history that will come in the museum space itself.

The success of these initiatives often hinges, interestingly enough, on the self- same effects that were previously identified as potentially problematic in the space of the gallery. We noted, for example, that 
highly aestheticized displays such as that in the Musée Picasso can have an inhibiting effect on the viewer's appreciation of the broader communication objectives the gallery might wish to draw out of the material on display. In fact the opposite occurs in the museum. Museum visitors are programmed to receive didactic messages via a range of often emphatic - and even occasionally hyperactively strained - communication strategies. The aestheticization effect, on the other hand, can provide a breath of fresh air in the museum. It often introduces what we might call slow space into the museum. This emphasis refocuses visitor attention not so much on the relentless drive towards the next interactive, as rather on a more open-ended expression of an evocative idea that is at the same time encapsulated in a work with its own integrity as an object of visual attentiveness in its own right.

The introduction of these new elements into the museum is nonetheless not without risk. As we have already begun to see, the new associations and ideas triggered by this process can at times detract from the integrity of the objector idea that the museum wishes to highlight. This might not pose such a significant problem for those museums that are not inherently concerned with maintaining the integrity of their objects or ideas. It may well be the case, for example, in the previously discussed cabinet from the Natural History Museum in London. Where, after all, is the harm in a little Damien Hirst referencing in an entrance exhibit of this kind? Yet for those museums, on the other hand, that do place a particular significance on the authority or artefactual status of either the objects in their collection or the ideas they promote, the stakes are undeniably higher. In these instances, the introduction of art and art-inspired displays can prove disruptive in ways that are in some cases still not fully acknowledged within the very spaces in which they are at the same time most effective.

An especially vivid example of this is provided by the US Holocaust Memorial Museum in Washington, DC.[7] The Holocaust Museum maintains an interesting policy regarding the collecting and display of contemporary art. On the one hand, it is very much in favour of drawing on the creative talents of contemporary artists. Yet, at the same time, it is equally insistent that art must remain separate from the permanent exhibitions. It has specific - and readily understandable- reasons for this, which it explains in the following terms: 'all exhibits should be of authentic documentary character in order to pre-empt attemptsby those who would deny that the Holocaust took place from using the Museumas supporting evidence for Holocaust denial.' [8]

To provide a presence for art in the Museum the designers accordingly elected to commission work from established mid-career artists, such as Ellsworth Kelly, Sol LeWitt, Richard Serra and Joel Shapiro. They then positioned these pieces in their so-called transitional spaces between and around the permanent exhibitions. Sol LeWitt's Consequence, for example, is sited in one of two 'lounges' designed as reflective spaces, creating momentary pauses in the circuit from one gallery of the permanent exhibition to another. Here the art acts as a kind of 'tonic' or reflective pause in between the relentless conveying of often highly confronting information in the galleries themselves. Effective as this strategy undeniably is, it nonetheless also brings to mind the previously noted tendency of art galleries to minimize information and communication technology elements within their displays. In each instance, it seems, the gallery, or here the museum, seeks to recognize the importance of a new and previously foreign element. Yet at the same time it also remains somehow mistrustful or ambivalent towards the very feature that it seeks otherwise to promote. So art is both welcomed and yet kept at arm's length in the museum space.

Even though art is banned from the galleries in the US Holocaust Memorial Museum, there is nonetheless a 
sense in which art-inspired concepts and display strategies have continued to play a significant - albeit unacknowledged - role in some of the exhibits. This is strikingly evident in a particularly powerful gallery filled with a heart-rending installation of shoes confiscated from concentration camp inmates. The display is in an important respect documentary, since it bears witness to the suffering of the inmates of Majdanek concentration camp. Yet a more generalized art effect is also evoked through the undeniable reference that it simultaneously creates to Joseph Beuys's use of similar strategies to evoke a contrast between the discarded trace remnants of individuals' lives, and the overloaded symbolic and relic-like significance that he at the same timewanted them to serve - often, in this respect, made via an association with the Holocaust.[9]

A similarly unacknowledged contemporary art reference occurs in a tower of faces that visitors walk through at another stage of the circuit. This displays photographs of an entire Jewish community executed by the SS in the space of two days. Clearly, the aura and archival status of these photographs is fundamental to their effect. And yet, in viewing them one is struck by both their massed display aesthetic, their quasi-religious and ritualistic memorializing effect, as well as by the way in which they, in the end, reinforce not so much a sense of the individuality of these Holocaust victims in particular, but rather a generalized and even collective sense of the anonymity of fadedness and loss. All these features unavoidably bring to mind the work of Christian Boltanski, who has followed similar themes relating to photographs of deceased or missing persons - including Holocaust victims - that he presents in similar ways.[10]

We might be justified in concluding, therefore, that there is something powerfully innovative about the US Holocaust Memorial Museum's deployment of art and art-inspired displays. At the same time, however, their policy remains also somehow ambivalent. Its unresolvedness seems to stem from the institution's admittedly understandable mistrust of the more ambiguous and unresolved emphases inherent within art when applied to their chosen subject area. Yet it is precisely these elements of open-endedness and evocativeness that make the previously mentioned art-inspired displays so effective. The displays constitute a perfect example of the slow space effect mentioned earlier. What makes them so powerful, from the point of view of this visitor at least, is their stark contrast to the rest of the exhibition spaces. Unlike the cumulatively hyperactive, didactically explicit and informationally overloaded displays that characterize the rest of the museum, these two moments make their points with an extreme clarity and efficiency of means.

So while characterizing these exhibits as slow spaces, we might also want to underline that their function is to operate in certain respects as free spaces as well. By this I mean that their mode of communication is arguably more effective precisely because it offers the viewer more space via a more multi-layered and openended emphasis that is markedly different from the more linear and traditionally didactic displays elsewhere in the museum. We need to recognize, of course, that it would not be appropriate for all or even most of the exhibits in the Holocaust Museum to operate in this way. If any museum is going to require didactic, dataheavy modes of information delivery, it is likely to be a museum devoted to this subject matter. Nonetheless, the success of these elements relative to the cumulative overload of the other displays raises the issue of the degree to which the competing effects and associations of art can be resolved - or indeed can even be acknowledged and formally addressed - in museum spaces of this kind.

We are thus reminded, once again, of the importance of the distinction between art galleries and museums that was raised by Bonnani at the outset of this discussion. Much as they have been drawing on the strengths and innovations of art galleries, museums will nonetheless tend to handle the issues here discussed in markedly different terms. A particularly clear demonstration of this can be gained if we compare two directly 
analogous communications messages framed in two recent, and in fact almost exactly contemporary, displays in Melbourne, Australia: a museum, on the one hand, as compared with an art gallery, on the other.

For many years the Melbourne Museum languished in cramped and run-down quarters that were almost buried under the weight of extensive nineteenth to twentieth-century encyclopaedic natural and social history collections. A resiting project nonetheless finally enabled this institution to radically rethink its mission.[11] The results are most powerfully evident in an area given overto a permanent exhibition of Aboriginal identity that is maintained semi autonomously by an indigenous department. The centrepiece is a cabinet focusing on the disputed legacy of the Anglo-Australian anthropologist, Walter Baldwin Spencer, director of the Museum from 1899 to 1928 . The Spencer cabinet makes manifest the common institutional ambivalence towards such 'father figures' in ethnographic museums founded on colonial collections. It does this by recasting Spencer as a hapless specimen imprisoned within his own display. In so doing, it ritually dethrones its founding father, installing him in a museological form of the stocks. The ritualistic element ofthe installation is intensified, once again, by the strong art effect that is present in the Museum's decision to depict Spencer not as a realistic effigy but as a marble-like sculpture - and thus as a kind of anti-memorial locked up in the prison of his own former possessions.

There is a certain poetic justice to this role reversal since it locates Spencer's memory in a denigrative form of display, just as Aboriginal people were represented in dioramas until relatively recently. $\mathrm{He}$ is also lampooned as anoutmoded and ridiculous figure with his whiskers and somewhat puzzled expression in the midst of it all. This impression is underscored by a nearby video display with an actor playing the role of an almost burlesquely ignorant Spencer who is brusquely inducted into some basic Aboriginal understandings by an impressively authoritative elder. A high degree of artistic licence is clearly at work in this portrayal of Spencer as a hapless and hopeless, disembodied ghost, who is both less present and corporeal, ironically enough, than the objects he collected.

The Spencer cabinet is an unforgettable and highly effective act of deliberate provocation against the prevailing emphases of traditional ethnographic museums. To gain some sense of its power in this respect, it might be worth noting that it would be akin to an institution like the Pitt Rivers Museum in Oxford electing to place a shrunken effigy of Pitt Rivers' own head within one of his former collections of shrunken and tattooed heads. Yet one could argue that this represents an appropriate emphasis in this instance given that this section of the Melbourne Museum is intended as an overtly politicized and impassioned presentation of Aboriginal people's own perspectives that it then seeks to reflect out to the visitor via the displays.[12]

In the end, however, statements of this kind are only as effective as their ability to cross the communications gap between the display and visitors themselves. In this respect, the Spencer cabinet, for all its undeniable power, might at the same time also run the risk of being both over determined to a certain degree, and also not as definitive as its designers might have hoped it to be. In the first instance, even though it adopts a broadly artistic approach, its strident communicative mode cancels out any sense of 'free space' such as was noted in the previous examples. In fact, the only free space available to the viewer is created if he or she goes against the grain of the display, so to speak. The exhibit is ostensibly concerned with critiquing the colonial practice of collecting and displaying ethnographic material culture as trophies of possession. And yet it seems simultaneously to undermine this reading through wall text that comments seemingly positively on the collecting process and through the great emphasis it in any event places on the beautifully lit, serried ranks of spears and other indexical artefacts of indigenous identity.[13] 
These comments are intended not so much as a critique of this exhibit in particular as rather a means of illustrating a more general observation concerning the gap that often exists between the on-paper clarity of an exhibition design, versus the often more complex reality of how it is received in the real time of completed display settings. The difficulties that arise from this gap should thus remind us of the importance of one overriding conclusion. That is, that objects and displays interact dynamically with visitors in complex ways that demonstrate their continued ability to evade curators' and exhibition designers' no doubt wellintentioned attempts to regulate and control their meanings. Visitors have the ability to experience displays on their own terms after all. And this obvious point once again highlights one of the great advantages of art and art inspired displays in contemporary museums. The open-ended and individualized effect of an art element in a museum setting - its ability, in effect, to break free of the museum's institutional voice - is one of its principle strengths. If this can be achieved in a way that also preserves the viewer's freedom to make his or her own connections from the material and ideas on display, then the initiative can be seen to have been highly successful indeed. A clearer sense of this can be gained if we contrast the previous example, by way of conclusion, to an exhibit in another directly comparable Melbourne institution, this time a gallery.

This exhibit occurs in The Ian Potter Centre: National Gallery of Victoria, Australia.[14] This institution was formed in 2001 as a result of the splitting into two of the National Gallery of Victoria's long-established and extensive collections of Australian and International art. Like the Melbourne Museum, this relocation also offered the Australian wing of the NGV the opportunity to rehang its collections along more contemporary lines. An emblematic example of this came in its decision to critically reframe one of its iconic colonial pieces. A hundred years earlier the Gallery had itself commissioned a grand commemorative painting of Captain Cook's previously mentioned landing at Botany Bay as a means of celebrating the recent unification of the Australian colonies under the act of Federation.[15] Now, a century later, it was able to restage the commission in a post-colonial setting to coincide with the opening of its new building It accordingly commissioned the Indigenous artist Julie Gough to create an installation that would respond to this painting as well as to one of her earlier works in the Gallery's collections, Imperial Leather, a piece that also interrogates colonial practices of the collecting and stereotyping of Aboriginal identity.[16] Chase accordingly evokes a tense and unresolved space between the historical moment and the contemporary situation. The ti trees that hang from the centre of the gallery represent once again the edge of the trees from which the Aboriginal people viewed Cook's landing as well as 'a place that has not been negotiated successfully and so remains our haunted house, our outdoors and indoors, our everywhere', as the artist has recently described it.[17]

In order to make the connection between the historical and contemporary explicit, the artist and the curators decided to take the additional step of removing the frame from the earlier painting. This strategy has two effects. On the one hand, it helps to break down the divisions between the works and to extend the painting out to the space of Gough's installation. Chase accordingly succeeds in creating the projective space that was noted previously as often lacking in gallery interiors. There is also a further sense in which the decision to remove the frame from a major late Victorian work constitutes a kind of ritualized debunking that would, of course, have been unthinkable in its own day. The NGVA, via the agency of its commissioned artist, has in effect ritually 'deframed' a painter whom they used historically to hold in the very highest regard. Their intervention is thus directly analogous to the Melbourne Museum's 'dethroning' of its founding father via an indigenous commentary on colonial collecting. In fact one could argue that the NGVA has gone further than the Melbourne Museum in this regard. For all its overtness, the Baldwin Spencer cabinet enacts its revenge 
on what is in the end only an effigy of Spencer and his legacy. The NGVA, by contrast, has taken an actual, key historical artefact in its collection and has physically intervened and overwritten it within the context of a contemporary art installation.

It is important to note in this context that it was the artist herself who enabled the NGVA to take this radical step. As non-practitioner, institutional representatives, the curators would have presumably not felt at liberty to implement such an initiative. But the artist acting as a kind of free agent was accorded an artistic licence that enabled her and the institution, in turn, to intervene in away that extends far beyond the traditional boundaries of curating works.[18] The result is an inherently projective space that makes just as strong and overta didactic statement as any museum display and yet does so in a way that also remains at the same time powerfully open-ended and evocative.

The foregoing analysis has stressed the processes of risk and ambiguity that have struck this writer as characteristic of all these indicative examples of the temporary conflation of contemporary gallery practices and spaces into the museum environment. The implications of these processes will need to be thought through further by the institutions in question. Museums will need in particular to bear in mind two key considerations that have been highlighted in this analysis. First is the degree to which these initiatives challenge traditional viewing expectations. As museum-goers and professionals alike will know full well, exhibition design remains a constantly developing field. Yesterday's contentious new initiative (think, for example, of the initial debate surrounding the supposed 'dumbing-down' effect of the multi-media interactive) can quickly become either standard fare - or even dated - within a surprisingly short time. In the meantime, however, visitors are often left to grapple with the often uncertain viewing conditions that are created by these shifting parameters of communications, which often exist side by side with earlier or in other respects contrasting communications formats.

Second, and leading on from the previous point, museums will need to address further the extent to which these initiatives match - or rather conflict with -the other communicative strategies employed elsewhere. As one example of this, in the Melbourne Museum the critical approach found in the Baldwin Spencer display appears at odds with the much more positive - even hagiographical -representation of Spencer's legacy that is found in the Museum's own official history. This publication describes the work of Spencer and his collaborator F. J. Gillen as having had 'a profound and lasting impact on European understanding and assumptions; and their systematic collecting yielded a rich and complex harvest of ethnographic material for the Museum'.[19] Visitors to the museum might well be justified in asking which of these two seemingly opposed characterizations is the more accurate.

And yet, as I hope also to have demonstrated, the potentially distracting and even destabilizing elements that are by-products of these new practices are also simultaneously the self-same features that make them so worthwhile. The initiatives here described have the potential to circumvent the anonymity and linearity of traditional didactic modes in order to model instead the kinds of more creative juxtapositions and reimaginings that museums should offer their visitors as a matter of course. They thus open up the tantalizing possibility of a dynamic conjunction between the projective space of the museum, on the one hand, and the reflective space of the gallery, on the other, that might serve as a yet more fertile ground for further synergies between both spaces in the near future. 


\section{Notes}

1 F. Bonanni, Notizie circa la Galleria del Collegio Romano, 1716, cited in P. Findlen, 'The museum: its classical etymology and Renaissance genealogy', Journal of the History of Collections, 1 (1), 1989: 60.

2 The classic study remains W. Prinz (ed. C. Cieri Via), Galleria: storia e tipologia di uno spazio architettonico, Modena: Panini, 1988.

3 For the Musée Picasso see D. Davies, The Museum Transformed: Design and Culture in the PostPompidou Age, New York: Abbeville Press, 1990, p. 52 and ff. for illustrations.

4 For this project see F. Asensio Cerver, The Architecture of Museums, New York: Hearst Books International, pp. 128-35.

5 For the Muséum national d'Histoire naturelle, Paris see Y. Laissus, Le Muséum national d'Histoire naturelle, Paris: Gallimard, 1995; H. de Lumley (ed.), Muséum national d'Histoire naturelle, Paris: Connaissance des Arts, 1995; J. Maigret, 'Aesthetics in the

service of science: the Grande Galerie de l'Evolution in Paris', Museum International, 48 (2), 190, 1996: 19-22.

6 For the Museum of Sydney see S. Hunt (ed.), Sites: Nailing the Debate, Archaeology and Interpretation in Museums, Sydney: Museum of Sydney, 1996; and D. Dysart (ed.), Edge of the Trees: A Sculptural Installation by Janet Laurence and Fiona Foley from the Concept by Peter Emmett, Sydney: Historic Houses Trust of New South Wales, 2000. For two more critical responses to the Museum see C. R. Marshall, 'Back in the basilica: the new museology and the problem of national identity in the Museum of Sydney', Art Monthly Australia, 100, June 1997: 7-11; and J. Marcus, 'Erotics of the Museum of Sydney', in J. Marcus, $A$ Dark Smudge Upon the Sand: Essays on Race, Guilt and the National Consciousness, Sydney: LhR Press, 1999, pp. 37-50.

7 J. Weinberg and R. Elieli, The Holocaust Museum in Washington, New York: Rizzoli, 1995.

8 Ibid., p. 29.

9 For associations between Beuys's work and the Holocaust see M. Biro, 'Representation and event: Anselm Kiefer, Joseph Beuys and the memory of the Holocaust', Yale Journal of Criticism, 16 (1), 2003: 113-46, particularly pp. 119-24. For a more critical reading of this topic see Z. Amashai-Maisels, Depiction and Interpretation: The Influence of the Holocaust on the Visual Arts, Oxford: Pergamon Press, 1993, pp. 346 and 501.

10 For associations between Boltanski's work and the Holocaust see E. van Alphen, Caught by History: Holocaust Effects in Contemporary Art, Literature and Theory, Stanford, CA: Stanford University Press, 1997, chapters 4 and 6, 'Deadly histories: Christian Boltanski's intervention in historiography', pp. 93-122 and 'The revivifying artist: Christian Boltanski's efforts to close the gap', pp. 149-75.

11 For the Melbourne Museum see C. Rasmussen, A Museum for the People: A History of Museum Victoria and its Predecessors, 1854-2000, Melbourne: Scribe Publications, 2001.

12 For this emphasis within contemporary Indigenous museum displays, and with a focus also on the Melbourne Museum, see G. Sculthorpe, 'Exhibiting Indigenous histories in Australian museums', in D. McIntyre and K. Wehner (eds), Negotiating Histories: National Museums Conference Proceedings, Canberra: National Museum of Australia in association with the Centre for Cross-Cultural Research and the Australian Key Centre for Cultural and Media Policy, 2001, pp. 73-84.

13 The information panels in the cabinet contain both negative and positive descriptions of collections and the collectors who contributed to the Museum. One panel, for example, notes that 'Until the early 1900s most objects came from small collections. These collections also provided some of the most precious, rare or 
unusual items.'

14 For The Ian Potter Centre: National Gallery of Victoria, Australia, see P. Goad, 'Enfilade and intrafilament: The Ian Potter Centre: NGV Australia at Federation Square', Art Bulletin of Victoria, 42, 2002: 7-15.

15 For E. Phillips Fox, The Landing of Captain Cook at Botany Bay 1770 (1902) see R. Zubans, E. Phillips Fox: His Life and Art, Melbourne: Miegunyah Press, 1995,

pp. $97-100$.

16 For Julie Gough's Imperial Leather (1994) see I. Crombie (ed.), Flagship: Australian Art in the National Gallery of Victoria, 1790-2000, Melbourne: The Ian Potter Centre, NGV Australia, 2002, p. 78.

17 The quotation occurs in an artist's statement reproduced as part of the wall text displayed alongside Chase during its exhibition in the NGVA from 2001 to 2004.

18 As a postscript to this point it nonetheless needs also to be noted that Julie Gough was subsequently appointed Curator of Indigenous Art at the NGVA two and a half years after the commission here discussed. 19 Rasmussen, Museum for the People, p. 140.

\section{References}

Amashai-Maisels, Z., Depiction and Interpretation: The Influence of the Holocaust on the Visual Arts, Oxford: Pergamon Press, 1993.

Asensio Cerver, F., The Architecture of Museums, New York: Hearst Books International, 1997.

Biro, M., 'Representation and event: Anselm Kiefer, Joseph Beuys and the memory of the Holocaust', Yale Journal of Criticism, 16 (1), 2003: 113-46.

Crombie, I. (ed.), Flagship: Australian Art in the National Gallery of Victoria, 1790-2000, Melbourne: The Ian Potter Centre, NGV Australia, 2002.

Davies, D., The Museum Transformed: Design and Culture in the Post-Pompidou Age, New York: Abbeville Press, 1990.

de Lumley, H. (ed.), Muséum national d'Histoire naturelle, Paris: Connaissance des Arts, 1995.

Dysart, D. (ed.), Edge of the Trees: A Sculptural Installation by Janet Laurence and Fiona Foley from the Concept by Peter Emmett, Sydney: Historic Houses Trust of New South Wales, 2000.

Findlen, P., 'The museum: its classical etymology and Renaissance genealogy', Journal of the History of Collections, 1 (1), 1989: 59-78.

Goad, P., 'Enfilade and intrafilament: The Ian Potter Centre: NGV Australia at Federation Square', Art Bulletin of Victoria, 42, 2002: 7-15.

Hunt, S. (ed.), Sites: Nailing the Debate, Archaeology and Interpretation in Museums, Sydney: Museum of Sydney, 1996.

Laissus, Y., Le Muséum national d'Histoire naturelle, Paris: Gallimard, 1995.

Maigret, J., 'Aesthetics in the service of science: the Grande Galerie de l'Evolution in Paris', Museum International, 48 (2), 190, 1996: 19-22.

Marcus, J., 'Erotics of the Museum of Sydney', in J. Marcus, A Dark Smudge Upon the Sand: Essays on Race, Guilt and the National Consciousness, Sydney: LhR Press, 1999, pp. 37-50.

Marshall, C. R., 'Back in the basilica: the new museology and the problem of national identity in the Museum of Sydney', Art Monthly Australia, 100, June 1997: 7-11.

Prinz, W. (ed. C. Cieri Via), Galleria: storia e tipologia di uno spazio architettonico, Modena: Panini, 1988.

Rasmussen, C., A Museum for the People: A History of Museum Victoria and its Predecessors, 1854-2000, Melbourne: Scribe Publications, 2001.

Sculthorpe, G., 'Exhibiting Indigenous histories in Australian museums', in D. McIntyre and K. Wehner 
(eds), Negotiating Histories: National Museums Conference Proceedings, Canberra: National Museum of Australia in association with the Centre for Cross-Cultural Research and the Australian Key Centre for Cultural and Media Policy, 2001, pp. 73-84.

van Alphen, E., Caught by History: Holocaust Effects in Contemporary Art, Literature and Theory, Stanford, CA: Stanford University Press, 1997.

Weinberg, J. and Elieli, R., The Holocaust Museum in Washington, New York: Rizzoli, 1995.

Zubans, R., E. Phillips Fox: His Life and Art, Melbourne: Miegunyah Press, 1995. 


\section{University Library}

\section{- M M N E R VA A gateway to Melbourne's research publications}

Minerva Access is the Institutional Repository of The University of Melbourne

Author/s:

Marshall, CR

Title:

When worlds collide: The contemporary museum as art gallery

Date:

2005-05-30

Citation:

Marshall, C. R. (2005). When worlds collide: The contemporary museum as art gallery. Macleod, S (Ed.). Reshaping Museum Space: Architecture, Design, Exhibitions, (1), pp.170-184. Routledge.

Publication Status:

Published

Persistent Link:

http://hdl.handle.net/11343/34721 